\title{
The Opportunity Costs of the Alaska Permanent Fund Dividend
}

\author{
Roger Marks ${ }^{1 *}$ \\ ${ }^{1}$ Principal, Roger Marks Economics, Anchorage, Alaska, United States \\ *Roger Marks, E-mail: rmarks@rmeconomics.com
}

Received: August 8, 2017

doi:10.22158/jepf.v3n3p430
Accepted: August 19, 2017

Online Published: August 25, 2017

URL: http://dx.doi.org/10.22158/jepf.v3n3p430

\begin{abstract}
The Alaska Permanent Fund was established by the State of Alaska in 1976 to save a portion of windfall revenues resulting from the discovery of the large Prudhoe Bay oil field. The Permanent Fund Dividend program, established in 1982, pays out about half the earnings of the Fund to each resident. The dividend was intended to both create a constituency for sound management of the Fund, and directly distribute the State's resource wealth to its citizens. The dividend has achieved great popularity, and has succeeded in allocating resource rents to boost jobs and personal income, and reduce poverty, while the Fund itself has grown. It has also protected the Fund from frivolous practices. But other sovereign wealth funds without dividends have also prospered. There have been trade-offs associated with the dividend, some of which have become more obvious with the Alaska economy grappling with the impact of chronic low oil prices. These include foregone earnings, political complexity, income inequality, and the question of public vs. private spending.
\end{abstract}

\section{Keywords}

Alaska Permanent Fund, Alaska Permanent Fund Dividend, sovereign wealth fund

\section{Introduction: The Origin of the Alaska Permanent Fund Dividend}

The discovery of the huge Prudhoe Bay oil field on the North Slope in 1967 led to profound changes in the Alaska economy. Construction of the pipeline to carry the oil to market was delayed, and the oil started flowing in 1977. Between 1970 and 1980:

- $\quad$ Population increased from 300,000 to 402,000 (Note 1)

- $\quad$ Employment increased from 133,000 to 211,000 (Note 2)

- $\quad$ Total personal income increased from $\$ 4.9$ to $\$ 8.7$ billion (Note 3)

- $\quad$ The state budget increased from $\$ 262$ million to $\$ 2.2$ billion (Note 4) (Note 5)

Subsequent to the discovery, a North Slope lease sale in 1969 yielded the state $\$ 900$ million, triple the annual budget, all of which was spent fairly soon. The spending reflected a combination of legitimate needs, anticipation of future oil revenues, future infrastructure requirements associated with the anticipated oil development, and also, in the minds of some, squandering. 
As former Governor Jay Hammond expressed:

Chief among these was to disperse money to municipalities in revenue sharing, which helped to lower taxes but gave little evidence to voters of anything concrete occurring or being constructed. As a result, many felt the windfall had been "blown" (Note 6).

The oil revenues that would accrue to the state would be very large. Between royalties and production, property, and state corporate income taxes, in 1980 the state would bring in $\$ 2.3$ billion, nearly 90 per cent of all revenues (Note 7).

Accordingly, regardless of how wisely the $\$ 900$ million had been spent, many believed it was important to save a portion of the oil revenues. First, people recognized that the size of the oil discovery was a once in a lifetime event and that the state would become wealthy. Savings could convert the field to sustainable economic prosperity and provide resources for future generations. Second, this would keep some money away from politicians.

In 1976 the Permanent Fund ("Fund") was created in a constitutional amendment. It mandated that at least 25 per cent of all mineral lease royalties, rentals, and bonuses be placed in the Fund. The principal could only be used for income-producing investments. A provision was added by statute in 1982 where the Legislature would transfer to the principal an amount of earnings sufficient to inflation-proof the fund each year (Note 8). Earnings also could be available for legislative appropriation, the same as other state General Fund (i.e., the budget) revenues.

In 1980, flush with oil money, the state eliminated its personal income tax. Though politically popular, this had a number of unfortunate side effects. First, it created a disconnect between economic development and state fiscal health (Note 9). Development increased the need for public spending, especially infrastructure, but without an income tax there was no source of funding linked to economic development.

Second, without an income tax there was reduced accountability by legislators and the public to curtail spending. They were mostly spending petrodollars.

And third, should those petrodollars diminish due to reduced production or lower prices, the budget would be severely impacted.

Jay Hammond was Alaska's governor from 1974-1982. Beyond championing the creation of the Permanent Fund as a savings device, he had other concerns.

Hammond worried that the earnings from the Fund would be readily spent by politicians, and that spending did not benefit everyone equally, and would deprive future generations of the benefit of the Fund. He also believed citizens had the right to share directly in the income from public assets, and that individuals could benefit more deciding themselves how to use the money (Note 10).

Thus he, to a large extent, and others, conceived and promoted the idea of having the Fund pay out an annual dividend to all Alaska residents (including children), which commenced in 1982 (The legal and political events that led to the creation of the Fund and dividend are described in detail by Groh (Note 11)). The dividend was established in statute and pays out about half the Fund's annual earnings (Note 
12).

Through 2016 about $\$ 21$ billion has been paid out in annual amounts ranging from about $\$ 300$ to $\$ 2100$ per Alaskan (Note 13). As of May 2017 the fund had grown to $\$ 55$ billion from royalty deposits (Note 14), investment earnings, and additional deposits by the Legislature in years of surplus state General Fund revenues (Note 15).

\section{The Achievements of the Dividend Program}

Judging by its popularity and growth the Alaska Permanent Fund Dividend program appears to have been successful. It is not difficult to understand how giving away money would be received (Note 16). The money has been used for the spectrum of college to retirement savings, to consumer durables and non-durables, to essentials and non-essentials.

As Hammond predicted, this has created a considerably strong constituency to defend the Fund, “... to encourage contributions into the investment account and to protect against its invasion by politicians by creating a militant ring of dividend recipients who would resist any such usage if it affected their dividends" (Note 17). The other associated result Hammond desired was to maximize returns from resource wealth.

In 1999 an advisory ballot initiative asking whether Permanent Fund earnings should be used to balance the budget, after paying dividends and inflation-proofing, was opposed by 83 percent of the electorate. As Goldsmith pointed out, "The fact that the governor called for an advisory vote on this question is particularly significant because the legislature already had the authority under law to appropriate not only the funds in the contingency account, but all the earnings of the fund" (Note 18) (Note 19).

To date no substantial amount of Fund earnings has been spent other than for dividends (and inflation-proofing) (Note 20). To do so would reduce dividends.

Hammond also correctly anticipated that the dividend would promote healthy resource development per the following criteria:

Is it environmentally sound? Do most Alaskans want it? Can it pay its own way and not require state subsidies? Does it provide maximum benefit to the people (Note 21)?

Hammond believed these criteria would be satisfied and citizens would support development when resources were profitable and paid royalties, which enriched the Fund and enhanced dividends.

The Fund has also contributed benefits to the economy. Goldsmith and Wanamaker found that in 1988 the dividend contributed 4.6 percent of personal income and 2.4 percent of total jobs (Note 22). In addition, as Alaska wrestles with budget issues surrounding low oil prices, in analyzing the short-run impacts of various revenue options Knapp, Berman, and Guettabi found that dividend cuts (as opposed to budget cuts, new taxes, or cuts in state jobs or salaries) would have the greatest short-run impact on individuals' income (Note 23). Long-run impacts are discussed below.

Moreover, for rural areas, with high costs and low employment opportunities, and for other low-income 
Alaskans, Berman and Reamey found the dividend reduced poverty rates for 15,000-25,000 Alaskans (out of a population of about 730,000) from 11 percent to 9 percent (Note 24) (Note 25).

Goldsmith attributes the success of the Fund to several additional factors in addition to the dividend (Note 26):

- The Fund was set up as a savings account to maximize long-run earnings that could be available for any purpose, rather than an economic development or infrastructure account. Investment was driven by economic rather than political factors (As Groh points out, pursuant to the run-up in oil prices in 1979, the state expanded economic development programs, which circumvented the need for the Fund to play that role) (Note 27).

- $\quad$ The Permanent Fund Corporation was set up as a separate institution whose sole purpose was to manage the Fund. It is highly respected.

- $\quad$ The Fund has invested very little in Alaska.

\section{The Fund at Low Oil Prices}

Alaska North Slope oil production peaked in 1988 (Note 28) at about 2 million barrels per day (Note 29). Since, production has been slowly declining. Now it is about at one-quarter of peak (Note 30).

At the same time oil prices were slowly increasing, as to offset the state revenue decline from the production decline, and oil revenues continued to provide a large share of the budget, nearly 90 percent (Note 31).

Oil prices had a precipitous rise starting in 2008, and began an even more precipitous decline starting in 2014. Between 2005, when oil prices were $\$ 45$ per barrel, and 2013, when they were $\$ 113$ per barrel, petroleum revenues increased from $\$ 2.8$ billion to $\$ 8.9$ billion. Between 2005 and 2013 the Alaska state budget increased from $\$ 2.6$ billion to $\$ 7.8$ billion (Note 32).

By 2017 oil prices were $\$ 39$ per barrel. In that year the state had a budget that had been cut to $\$ 4.3$ billion, but revenues of only $\$ 1.2$ billion, a deficit of $\$ 3.1$ billion, 72 per cent of its revenues (Note 33). The large deficits since 2014 have been financed by a separate savings account, the Constitutional Budget Reserve Fund (CBR) (Note 34). The CBR was established in 1990 and consists of settlements from oil and gas tax and royalty disputes. It was intended to function as the state's emergency supply of cash. That fund will be nearly empty by the end of 2018 .

Since 2014 the Alaska Legislature has been struggling with the problem of balancing the budget. In addition to enacted budget cuts (Note 35), and proposed increased revenue measures, which to date have not passed, there is general consensus among most legislators that some earnings from the Permanent Fund should fund government. The Legislature has not agreed on the details. The main points of contention are somewhat the percentage of earnings to be used, but more important, what portion of those earnings should go to dividends.

The Governor did veto half the appropriation for the dividend in 2016. In 2017 the legislature only appropriated the funds for half the formula-driven dividend amount. As a result the dividend still 
accounted for about $\$ 700$ million, or 16 percent of the budget.

At the same time the state economy is in recession, due in part to the impact of low oil prices on the state's petroleum sector, a significant part of the economy, and due in part to reduced state spending. The state's bond rating has been downgraded, attributable to the recession, reduced state revenues, and the absence of a sustainable budget plan (Note 36).

\section{Opportunity Costs}

While much has been written about the success of the dividend program, less attention has been paid to the trade-offs inherent with the plan. Within Alaska, which would attract the most concentration, as Goldsmith observed, "since most Alaskans view the dividend as a distribution of their wealth, they see no reason to study it as a phenomenon, and actually look on any attempt to study the dividend as a potential threat to its existence" (Note 37).

Outside Alaska most of the emphasis has been on the dividend as a model of basic income guarantees (Note 38).

With that background, the focus will be to examine in retrospect the issues that have been presented by the dividend, particularly what alternatives to the dividend might have meant. Some of these become manifest in the context of an economy that has been significantly weakened by a sudden large unexpected drop in oil prices, a relatively recent occurrence. The following will be examined in that context:

- $\quad$ Foregone returns on dividend amounts

- $\quad$ Political complexities presented by the dividend

- $\quad$ Income disparity

- $\quad$ Private vs. public spending

Some of these issues were briefly cited by Goldsmith (Note 39) and Knapp (Note 40). Additional concerns they mentioned, not addressed here, include:

- $\quad$ The dividend is taxed by the federal government.

- $\quad$ The perception fostered by the dividend reduces federal aid to the state.

- $\quad$ The dividend creates a culture of consumption and dependence on government.

- The dividend subsidizes wages for Alaska employers, who can reduce what they need to pay to attract workers from outside by the amount of the dividend.

\subsection{Foregone Returns}

At a high level, what if dividends had never been paid? Had the $\$ 21$ billion never been paid out, but rather kept in the Fund, earning the same total return the Fund made, there would now be an estimated $\$ 80$ billion more in the Fund (Note 41), for a total of $\$ 135$ billion (145 percent more) (See Appendix A).

With annual earnings of 5 percent the Fund would have been able to generate $\$ 6.75$ billion in state spending, 57 percent more than the current unrestricted General Fund budget, with the need for no 
other revenues. There currently would be no budget problem, no reduction in bond rating, and some easing of the recession (albeit the dividend has elevated the baseline economy). Alternatively, the amount would have been available for counter-cyclical spending in times of low oil prices. In that regard the dividend has directly weakened the Fund.

Of course, Alaskans have been enjoying that money over the years. And as discussed above, zealous defense of the dividend protected the Fund from imprudent investing, or risky or politically motivated attempts at internal economic development, or runaway spending. And the dividend circulated in the Alaska economy.

But can it be said that sacrificing $\$ 80$ billion preserved the Fund? And was it necessary, or the only way, to safeguard the corpus? How were intergenerational distributions affected?

Of the scores of sovereign wealth funds worldwide, Alaska is the only one that pays a dividend (Note 42). Yet without a dividend many of these other funds do not appear to be plagued by those problems. They generally contain a professionally managed, well-diversified portfolio (Note 43).

As a counterexample to the dividend argument, Alaska can be specifically compared to Norway's Government Pension Fund Global (GPFG). The GPFG was established in 1998 for a very similar purpose to the Permanent Fund: to save petrodollars by maximizing investment returns.

The source of funds is the net cash flow from petroleum activities. Gross revenues include taxes and royalties, operating income and dividends from Norway's direct financial interest in the company Statoil (almost 70 percent), and the investment returns. Expenses include the direct investments and operating costs in Statoil's commercial petroleum activities (Note 44). Their fund is now worth nearly a trillion dollars, about twice as much per capita as Alaska (Note 45) (Norway was able to save 100 percent of its oil and gas money because it retained its VAT and personal income tax when the oil dollars started to flow).

GPFG's goal is to maximize return with moderate risk. It establishes benchmark indices, which it usually exceeds. Per its investment rules the fund may not invest in Norwegian securities or infrastructure or economic development (Note 46).

Between 1998-2016 the Norwegian fund has earned an average annual total return of 5.7 percent (Note 47). The Alaska Permanent Fund in the same period earned 6.8 percent. GPFG's lower return may be due, in part, to more conservative investment limits than Alaska (Note 48), an extensive list of investments and companies forbidden due to ethical concerns (Note 49), and currency fluctuations.

Norway is allowed to use up to 4 percent of the GPFG principal in its annual budget. In 2016 for the first time, owing to slumping oil prices and revenues, Norway appropriated about 1 percent of the GPFG fund's market value for its budget (Note 50), and 3 percent in 2017 (Note 51).

Both jurisdictions had high revenues during high oil prices. And though Norway had a broad-based tax, in both jurisdictions revenues were not sufficient to cover the budget during low oil prices.

Using savings to fund government is similar to what Alaska has done in depleting its Constitutional Budget Reserve Fund since 2014, and what it will inevitably do with the Permanent Fund after. In that 
regard the dividend did not provide protection from using savings.

In summary, Norway, as an example, has managed to avoid all the pitfalls the dividend addressed without a dividend.

Moreover, since 2000 many of the oil-based sovereign wealth funds larger than Alaska (Abu Dhabi, Saudi Arabia, Qatar, Kazakhstan, Kuwait) have either increased the assets under management or earned returns at rates similar to Alaska (Note 52).

These economies, too, had surplus revenues at high oil prices, and increased spending accordingly (like Alaska). While it could be argued that those expenditures served the function of the dividend by keeping pressure off the fund, at low prices these jurisdictions are cutting budgets, but still making deposits into their funds while using some fund earnings (like Alaska). Accordingly, their funds have continued to stay even or grow even at low oil prices (Note 53).

Total sovereign wealth fund assets under management worldwide have increased from \$1 trillion to \$7 trillion between 2000 and 2015 (Note 54).

But that is not to say all sovereign wealth funds have succeeded. Many have not had significant growth. The Alberta Heritage Savings Trust Fund, for example, has not increased in value in many years. This is attributable to many factors. The fund in Alberta had no rigorous deposit regime while government spending was increased, and money from the fund was directed toward local economic development in Alberta, capital infrastructure, and loans (Note 55) (Note 56).

Similarly, in Venezuela, money was taken from the principal for public spending (Note 57). In Texas, earnings from their fund are explicitly earmarked for education (Note 58). In Iraq money from the principal was diverted for food, electricity and oil infrastructure, and equipment for Iraqi security forces, civil service salaries and ministry budget operations (Note 59).

In these jurisdictions there was either no rigorous deposit process, the principal was available for spending, or earnings were used continually for internal purposes (infrastructure, economic development, general government spending). The former two actions could not occur under Alaska's structure with or without a dividend; the latter one could.

There are two other observations regarding the foregone income:

First, Alaska may have avoided all the drawbacks the dividend was meant to circumvent, and accrued a larger current balance in the Fund, by paying out somewhat less than 50 percent of the earnings in dividends.

Second, should future dividends be reduced, or broad-based tax liabilities introduced, due to the consequences of past dividend amounts and foregone earnings, this may represent a front-end loading of the inter-generational distribution of the resource wealth. To the extent the state's future budget problems cause more Fund earnings to be used for the state budget and less for dividends, or result in the institution of a statewide property or personal income tax because the Fund balance is too low to cover the budget gap, past Alaskans may have received a greater benefit from the Fund than future ones. Of course to the extent the dividend protected the Fund this will not be the case. 


\subsection{Politics}

Financing a dividend at a time of budget deficits is problematic. While no clear consensus seems to be emerging about what the size of Alaska state government should be, there does appear to be conceptual agreement about how to pay for the Permanent Fund Dividend, and these are connected.

Up until now the money to pay the dividend has been isolated from the state budget. Only dividends were paid out of Permanent Fund earnings. And the budget to run government came from revenues, plus, recently, subsequent to the collapse in oil prices, draws from the CBR. Dividends and General Fund spending came from different pots, and were not in competition with one another.

With the CBR nearly depleted, since it is highly unlikely that budget cuts or new tax revenues will fill the entire gap, it is inevitable that part of government will be funded by Permanent Fund earnings. Earnings will be brought in as a revenue item, just like other General Fund unrestricted items, and be available for appropriation. The earnings will be allocated between running government and the dividend. And the dividend will be appropriated out of the total available revenues. At that point, the dividend becomes inextricably linked to the budget.

This will be a game changer. The total amount available for state spending and dividends will be fixed under legislative proposals to limit the annual draw to a set percentage of the Fund's total market value. It will be a zero-sum game. Funding the dividend will now require either de-funding something else or raising additional revenue.

The FY 2018 budget has $\$ 760$ million for the dividend (Note 60). At the same time a proposed income tax, which passed the House but not the Senate, would have brought in about \$700 million (Note 61). Some taxes would come from out-of-state residents who work in Alaska, and there would be some income re-distribution. But many Alaskans saw that either as nothing more than paying taxes from themselves to pay dividends to themselves, or as some Alaskans paying taxes in order to give dividends to others.

However, some Alaskans have no problem with combining the dividend with an income tax insofar as they view the dividend not as a part of public spending, but rather as the annual distribution of their ownership share of the publicly owned resource.

In addition, the budget and dividend mechanism in using Permanent Fund earnings to fund both government and dividends presents risks at low oil prices; it increases the effect of oil price volatility.

Some ongoing state revenues would still come from oil taxes and royalties, which depend on oil prices. Dividends would consist of a portion of the Permanent Fund earnings, which is independent of oil prices. Under that mechanism, at low oil prices state revenues drop precipitously while dividends are unchanged. At low prices the dividend takes up an increasing share of the limited revenues.

At low prices more Fund earnings would be needed to balance the budget. But because of the dividend, again, either spending on something else would be reduced, or revenues (taxes) increased. Is it more important for services, or the dividend, to be stable if oil prices fall?

Thus the only sustainable source of budget funding is Permanent Fund earnings (even with a broad-based 
tax). So paying the dividend means either bigger budget cuts (less public spending), higher taxes to pay for the dividend, or a higher earnings draw from the Fund, which threatens its sustainability.

Each of these options has constituencies that both favor and oppose each option. Many Alaskans now feel the main purpose of the Fund is not a savings account, but to generate dividends (Note 62). And like most entitlements, it is difficult to take back. The 2016 dividend veto mentioned above was not popular. That veto led to litigation challenging the Governor's authority to veto half the dividend appropriation, an effort to recall the Governor, and a decline in the Governor's approval rating.

The existence of the dividend in the debate has created divisiveness in the attempt to get to a long-run sustainable budget plan. As a result the CBR Fund has been drawn down, whose diminishment threatens the Permanent Fund (Note 63).

\subsection{Income Equality}

The State of Alaska owns about 24 percent of the acreage statewide, and much of the land containing North Slope oil leases. Its constitution calls for managing public resources for "the maximum benefit of its people". Governor Hammond often quoted that provision in promoting the dividend.

Article 1 of the Alaska constitution begins with a Declaration of Rights. Section 1 of the article contains Inherent Rights, and says, “... all persons have corresponding obligations to the people and to the State".

Median family income in Alaska was $\$ 83,000$ in 2014 , the fifth highest state in the country; half the families make more than that amount (Note 64). So frankly, does everyone need the dividend? If not, should everybody get it? Or could the part that goes to high-income people be put to better use? Are there more efficient ways to help lower-income Alaskans than paying the same fixed amount to everyone?

The Economic Policy Institute and the Center on Budget and Policy Priorities found that in Alaska the wealthiest 5 percent of households have incomes nearly 11 times higher than the poorest 20 percent, and that between the late 1990's and mid-2000's average income among the bottom 20 percent dropped 9.2 percent (Note 65). The poverty rate in Alaska is 9 percent and rising (Note 66).

There is no intrinsic reason why every citizen deserves the dividend. Much of the dividend is the result of the efforts of the body politic of previous generations.

Much has been written regarding the moral dimensions of income inequality. For example, Scalon has noted that income inequality:

- $\quad$... can give wealthier people an unacceptable degree of control over the lives of others.

- $\quad$... can undermine the fairness of political institutions.

- $\quad . .$. undermines the fairness of the economic system itself (Note 67).

In addition, the generally accepted laws of diminishing marginal utility of income and wealth suggest that as income increases, individuals gain a correspondingly smaller increase in satisfaction and happiness; re-distributing income from the rich to the poor raises the well-being of the poor by more than it reduces it of the rich. The quality of life of lower income people can be made correspondingly better without undue burdens on the higher income. 
Thus the policy of paying the same amount to everyone, with dividends being paid to higher income Alaskans, could be diverted to address the problems of income inequality and poverty. In addition to cash, this could take the form of housing, energy, food, health, and education, where the latter set can be delivered to multiple households more efficient.

Given the lower propensity to save by lower-income people, this could also result in an enhanced economic impact relative to the current program.

\subsection{Private vs. Public Spending}

In establishing the dividend Hammond wanted "to pit collective greed against selective greed," the former being personal interests, and the latter being public, where not all Alaskans benefited from state spending, and some waste is inevitable (Note 68).

The Permanent Fund, and the dividend, are originally products of surplus windfall revenues, surpluses relative to an existing baseline. Without the excess there could have been no savings account and derivative revenues. A choice between individuals receiving money now or public spending (either one limited to only a portion of Fund earnings) is a choice very few other jurisdictions could offer.

There are well-documented observations in behavioral psychology and economics regarding the partiality of instant vs. delayed gratification. The immediate reward can be visualized better, it comes sooner, and is more reliable to occur (Note 69).

In addition, there is the financial duress many households find themselves in. In a way, the "collective greed" never had a chance.

The "correct" size of government is always a subjective moving target. In his comments for announcing the size of the dividend in 2002, the commissioner of the Department of Revenue, Wilson Condon said:

People for centuries have chosen government as the means to achieve the goals of an organized community, the delivery system for many of the needs of society such as schools, roads, justice and health systems ... Everyone benefits from services delivered by government ...

Similarly, Cummine pointed out that Sovereign Wealth Funds (SWFs):

... are first and foremost savings vehicles for the citizen body as a collective. Individuals have a right to benefit from this wealth but vis-à-vis their membership of the community, not in their capacity as private individuals. Even if private rights to this wealth are found to exist, such rights would be trumped by jointly held rights to this common wealth. This is reflected explicitly in the establishing documents of many SWFs, which conceive of SWFs as national savings funds set up to ring-fence capital to help meet long-term community liabilities (Note 70) (Cummine was actually arguing against the "anti-dividend posture" that dividends are consumption that should be invested, they dilute returns relative to being invested en masse, they belong to the citizens as a collective, and may impair the jurisdiction's ability to affect macroeconomic adjustments).

It is not a question of public spending undermining private enterprise; again, the capital for the dividend was earned by the government. The alternative perspective is that the dividend not a part of public 
spending, but rather the annual distribution of the ownership share of the publicly owned resource.

Public spending could nurture its own constituencies to protect the fund, and grow the economy, as well. Moreover, the use of earnings to obviate an income tax could also have considerable support.

In their aforementioned study Knapp, Berman, and Guettabi found, relative to other fiscal options, that cutting the dividend would have a greater short-run impact on income (Their charge was only to look at the short-term). But they also said:

Choices Alaskans make about closing the budget deficit would affect Alaska's economy and society in many important ways beyond the short-term economic impacts we estimated for this study. We should base our fiscal choices not only on their short-term effects but also on what they might mean for Alaska's economy and society over time (Note 71).

Over the long-run systematic cuts to services (health, education, safety, workforce training, transportation infrastructure and maintenance, fisheries management, etc.) could have impacts on the quality of life. In that situation, having caused reduced services, could the dividend itself have made Alaskans better or worse off?

\section{Conclusion}

The Alaska Permanent Fund Dividend is a unique program. It has shaped the distribution of petrodollars directly to citizens to a remarkable degree, and has protected the Fund from frivolous practices.

Like all financial choices, proceeding in one direction meant precluding others. This analysis attempted to examine what alternative options may have been possible, and their merits and disadvantages.

Some of these issues, like foregone earnings and political complexity, only became apparent at low oil prices. Others, like the choice between private and public spending, and income distribution, involve judgments on what constitutes a civil society, and whether individuals or the collective are the beneficiaries of the resource.

There are scores of other sovereign wealth funds worldwide, and no other jurisdiction has a similar program. The Norwegian model, and others, showed a fund can be successful without a dividend if other rigorous management practices are upheld. Perhaps there are cultural idiosyncrasies endemic to Alaska that makes the dividend more appropriate. Other jurisdictions considering a dividend may want to reflect on what the dividend meant for Alaska, and what Alaska sacrificed.

The political temptation to spend on unsound economic development or infrastructure can be intense. In Alaska, beyond spending earnings, the value of the Fund can also be eaten away by not inflation-proofing, or borrowing from the Fund to pay off debts that may never be repaid.

The dividend has been an effective protector of the Fund because the citizens had a direct financial stake in its management. The absence of it would have required thorough safeguards: rigorous deposits, protection of the corpus, and the judicious consideration on the use of earnings. 


\section{References}

Berman, M., \& Reamey. (2016, November). Permanent Fund Dividends and Poverty in Alaska. University of Alaska, Institute of Social and Economic Research.

Cummine, A. (2011, October). Overcoming Dividend Skepticism: Why the World's Sovereign Wealth Funds are Not Paying Dividends. Basic Income Studies.

Goldsmith, S. (2011, January). The Alaska Permanent Fund Dividend: A Case Study in the Direct Distribution of Resource Rent. University of Alaska, Institute of Social and Economic Research.

Hammond, J. (2012). Diapering the Devil: How Alaska Helped Staunch Befouling by Mismanaged Oil Wealth: A Lesson for Other Oil Rich Nations. Center for Global Development.

Knapp, G. (2007, July 11). Four Alaska Innovations. Presented to the Board of Directors of the Federal Reserve Bank of San Francisco and its Seattle Branch.

Knapp, G., Berman, M., \& Guettabi, M. (2016, March). Short-Run Economic Impacts of Alaska Fiscal Options. University of Alaska, Institute of Social and Economic Research.

Widerquist, K., \& Howard, M. (Eds.). (2012a). Alaska's Permanent Fund Dividend: Examining Its Suitability as a Model. New York: Palgrave MacMillan.

Widerquist, K., \& Howard, M. (Eds.). (2012b). Exporting the Alaska Model: Adapting the Permanent Fund Dividend for Reform around the World. New York: Palgrave MacMillan.

\section{Notes}

Note 1. Goldsmith, S., \& Hill, A. (1997, March). Alaska's Economy and Population, 1959-2020 (p. 6). University of Alaska, Institute of Social and Economic Research. Retrieved from http://www.iser.uaa.alaska.edu/Publications/1970-EconomySix.pdf

Note 2. Ibid.

Note 3. Ibid.

Note 4. Alaska Review of Business and Economic Conditions: Fiscal Data for Alaska (p. 24). (1975, June). University of Alaska, Institute of Social and Economic Research. Retrieved from http://www.iser.uaa.alaska.edu/Publications/formal/arsecs/arbec/ARBEC_XII2_Fiscal_DataAK.pdf

Note 5. The Alaska Citizen's Guide to the Budget. (2003). University of Alaska, Institute of Social \& Economic Research. Retrieved from http://www.citizensguide.uaa.alaska.edu/3.SPENDING_ HISTORY/3.2.Growth_of_Total_Appropriations.htm

Note 6. Hammond, J. (2012). Diapering the Devil: How Alaska Helped Staunch Befouling by Mismanaged Oil Wealth: A Lesson for Other Oil Rich Nations (p. 20). Center for Global Development (Hammond summarized his outlook in this piece towards the end of his life. He passed away in 2005. The draft was in an advanced stage. It was completed by his granddaughter, Lauren Stanford. The title refers to Hammond's perspective, regarding the impact it had on communities, that oil was the "devil's excrement”). Retrieved from https:/www.cgdev.org/files/1426542_file_Ch2_GovernorsSolution.pdf Note 7. Revenue Sources FY 1980-1982, Quarterly Update (p. 6). (1980, September). State of Alaska Published by SCHOLINK INC. 
Department of Revenue. Retrieved from http://www.tax.alaska.gov/programs/documentviewer/ viewer.aspx?944r

Note 8. http://www.law.state.ak.us/pdf/opinions/opinions_2003/03-011_663030153.pdf

Note 9. Knapp, G. (2015, Spring). Resource Revenues and Fiscal Sustainability: Lessons of the Alaska

Disconnect. Economic Development Journal. Retrieved from http://www.iedconline.org/web-pages/resources-publications/economic-development-journal-spring-20 $15 /$

Note 10. Hammond, op. cit.

Note 11. Groh, C. (2012a). The Improbable but True Story of How the Alaska Permanent Fund and the Alaska Permanent Fund Dividend Came to Be. In K. Widerquist, \& M. W. Howard (Eds.), Alaska's Permanent Fund Dividend: Examining Its Sustainability as a Model (pp. 15-39). Palgrave MacMillan.

Note 12. The dividend is calculated as 21 percent of the average of the previous five years' earnings, distributed to all eligible Alaskans.

Note 13. http://www.pfd.alaska.gov/Division-Info/Summary-of-Applications-and-Payments

Note 14 . Until recently the royalty contribution rate from newer (and smaller) fields was increased to 50 percent.

Note 15. http://www.apfc.org/_amiReportsArchive/APFC201705.pdf

Note 16. In a January 17, 2017 op-ed in the Alaska Dispatch News the author, addressing this topic, cited the Jerry Seinfeld line that "People don't turn down money. This is what separates us from animals".

Note 17. Hammond, op. cit., p. 19.

Note 18. Goldsmith, S. (2011, January). The Alaska Permanent Fund Dividend: A Case Study in the Direct Distribution of Resource Rent. University of Alaska, Institute of Social and Economic Research. Retrieved from https://www.pdfs.semanticscholar.org/cebd/f0711f0e20967ff82c7d621af9c16dbceebc. pdf

Note 19. By 2015 poll by the Rasmuson Foundation found that 66 percent of Alaskans favored using some Fund earnings for public services and programs, while protecting the dividend program.

Note 20. Small amounts of earnings are appropriated each year to pay to administer the dividend program, to cover the "hold-harmless" provision so that public assistance recipients do not lose their monthly benefits when the dividend puts them over-income for the months, to cover some programs at the Department of Corrections, and to help fund royalty work at the Departments of Law and Natural Resources.

Note 21. Hammond, op.cit., p. 29.

Note 22. Goldsmith, S., \& Wanamaker, J. (1989, September). The Economic Impact of the Alaska Permanent Fund Dividend (p. 24). Prepared for the Alaska Permanent Fund Corporation. Retrieved from http://www.iser.uaa.alaska.edu/Publications/Economic_Impacts_AK_PFD.pdf

Note 23. Knapp, G., Berman, M., \& Guettabi, M. (2016, March). Short-Run Economic Impacts of Alaska Fiscal Options. University of Alaska, Institute of Social and Economic Research. Retrieved from Published by SCHOLINK INC. 
http://www.iser.uaa.alaska.edu/Publications/2016_03_30-ShortrunEconomicImpactsOfAlaskaFiscalOpt ions.pdf

Note 24. Berman, M., \& Reamey, R. (2016, November). Permanent Fund Dividends and Poverty in Alaska. University of Alaska, Institute of Social and Economic Research. Retrieved from http://www.iser.uaa.alaska.edu/Publications/2016_12-PFDandPoverty.pdf

Note 25. State of Alaska Department of Labor and Workforce Development, 2017.

Note 26. Goldsmith, op. cit. 2011.

Note 27. Groh, op. cit.

Note 28. All years are fiscal years beginning July 1.

Note 29. Alaska Department of Revenue, Tax Division. Revenue Sources Book Fall 2008 (p. 19). Retrieved from http://www.tax.alaska.gov/programs/documentviewer/viewer.aspx?886r

Note 30. Alaska Department of Revenue, Tax Division. Revenue Sources Book Fall 2016 (pp. 113-114).

Retrieved from http://www.tax.alaska.gov/programs/documentviewer/viewer.aspx?1321r

Note 31. Alaska Division of Legislative Finance. Retrieved from http://www.legfin.akleg.gov/

Note 32. Ibid.

Note 33. Ibid.

Note 34. The CBR has helped cover deficits in about half the years since it was established, but at much smaller amounts than post-2014.

Note 35 . The 2017 real per capita budget is about 9 per cent higher than in 2005 , rising health care costs being a significant contributor.

Note 36. https://www.adn.com/business-economy/2017/07/18/s-second-downgrade-in-one-week/

Note 37. Goldsmith. The Economic and Social Impacts of the Permanent Fund Dividend on Alaska. Widerquist, op.cit, 2012(a), p. 49.

Note 38. For example, see Widerquist. 2012(a) or K. Widerquist, \& M. W. Howard (Eds.), Exporting the Alaska Model: Adapting the Permanent Fund Dividend for Reform around the World. Palgrave MacMillan.

Note 39. Goldsmith (2011), op. cit.

Note 40. Knapp, G. (2007, July 11). Four Alaska Innovations. Presented to the Board of Directors of the Federal Reserve Bank of San Francisco and its Seattle Branch.

Note 41. https://www.file:///Users/rogermarks/Downloads/Historical\%20Values_APF\%20(1).pdf

Note 42. Cummine, A. (2011, October). Overcoming Dividend Skepticism: Why the World's Sovereign Wealth Funds are Not Paying Dividends. Basic Income Studies.

Note 43. For example, see Preqin. 2015 Preqin Sovereign Wealth Fund Review: Exclusive Extract. Retrieved from https://www.preqin.com/docs/reports/2015-Preqin-Sovereign-Wealth-Fund-ReviewExclusive-Extract-June-2015.pdf or Dyck, A., \& Morse, A. (2011). Sovereign Wealth Fund Portfolios. The Milton Friedman Institute for Research in Economics. Retrieved from http://www.bfi.uchicago.edu/RePEc/bfi/wpaper/BFI_2011-003.pdf 
Note 44. Ministry of Finance, Norway. (October 2012). Provisions on the management of the Government Pension Fund. Retrieved from https://www.regjeringen.no/en/topics/the-economy/thegovernment-pension-fund/the-guidelines-for-the-management-of-the/id434605/

Note 45. Norges Bank. (p. 7). Government Pension Fund Global 2016 Annual Report. Retrieved from https://www.nbim.no/contentassets/41460fa6a42b4bd4a758429b90f80da2/government-pension-fund-gl obal---annual-report-2016.pdf

Note 46. Ministry of Finance, Norway. (2010, November). Management mandate for the Government Pension Fund Global. Retrieved from https://www.nbim.no/en/the-fund/governance-model/ management-mandate/

Note 47. Norges Bank, op. cit., p. 18.

Note 48. Norges Bank, op. cit., p. 23.

Note 49. Norges Bank. (2015, January). Observation and Exclusion of Companies. Retrieved from https://www.nbim.no/en/responsibility/exclusion-of-companies/

Note 50. CNBC. (2016, March 7). Norway taps its oil fund for the first time. Retrieved from https://www.cnbc.com/2016/03/07/norway-taps-its-oil-fund-for-the-first-time.html

Note 51. Reuters. (2017, May 11). Norway 2017 budget reduces spending of cash from wealth fund. Retrieved from http://www.reuters.com/article/us-norway-budget-idUSKBN18712N

Note 52. http://www.swfinstitute.org/swfs/abu-dhabi-investment-authority/

http://www.swfinstitute.org/swfs/sama-foreign-holdings/

http://www.swfinstitute.org/swfs/qatar-investment-authority/

http://www.sovereignwealthcenter.com/fund/46/national-fund-of-the-republic-of-kazakhstan.html\#/.W YJD61KpXIU

http://www.fletcher.tufts.edu/ /media/Fletcher/Microsites/swfi/pdfs/2012/profiles/KIA\%20Fund\%20Pr ofile_v2.pdf

Note 53. http://www.file:///Users/rogermarks/Downloads/Accountability\%20Report\%202016\%20(1). pdf

http://www.sama.gov.sa/en-US/EconomicReports/AnnualReport/Fifty\%20Second\%20Annual\%20Repo rt.pdf https://www.qatarinvestmentfund.com/fileadmin/uploads/qif/Documents/Annual_Reports/Epicure_Qat ar_30_06_2015_Final_no_AGM-Proxy.pdf https://www.kfh.com/en/reports/Annual-Reports/Annual-Report-2016/document_en/English.pdf.pdf http://www.nationalbank.kz/?finalDate $=5.01 .2003 \&$ finalDate2 $=25.12 .2017 \&$ dates $=+$ To + display + the $+\mathrm{i}$ nformation\&tab_id=15\&lang=eng\&docid=180\&arch_show=on\&ch_date=on\&switch=english Note 54. Kalter, E. (2016, January). Sovereign Wealth Fund Investment Trends (p. 6). Tufts University. Retrieved from http://www.fletcher.tufts.edu/ /media/Fletcher/Microsites/SovereigNET/Kalter_SWF\% 20Investment\%20Trends.pdf

Note 55. Alberta Heritage Savings Trust Fund 2016-17 Annual Report. Retrieved from Published by SCHOLINK INC. 
http://www.finance.alberta.ca/business/ahstf/

Note 56. Milke, M., \& Palacios, M. (2015, February). Fumbling the Alberta Advantage. Fraser Institute.

Retrieved from https://www.fraserinstitute.org/sites/default/files/fumbling-the-alberta-advantagerev.pdf

Note 57. http://www.swfinstitute.org/swfs/fem/

Note 58. http://www.tea.texas.gov/Finance_and_Grants/Texas_Permanent_School_Fund/Texas_ Permanent_School_Fund_-_Annual_Report/

Note 59. https://www.en.wikipedia.org/wiki/Development_Fund_for_Iraq

Note 60. http://www.legis.state.ak.us/PDF/30/Bills/HB0057Z.PDF

Note 61. http://www.legis.state.ak.us/PDF/30/F/HB0115-2-4-041217-REV-Y.PDF

Note 62. Goldsmith (2011), op.cit, p. 19.

Note 63. https://www.adn.com/politics/2016/10/07/alaska-gov-walkers-popularity-dives-sharplyfollowing-pfd-veto-new-survey-shows/

Note 64. https://www.en.wikipedia.org/wiki/List_of_Alaska_locations_by_per_capita_income

Note 65. Economic Policy Institute/Center on Budget and Policy Priorities. (2012, November). Pulling Apart: A State-by-State Analysis of Income Trends. Retrieved from https://www.cbpp.org/sites/default/files/atoms/files/Alaska.pdf

Note 66. Berman and Reamey, op. cit.

Note 67. Scalon, T. M. (2014, June). The 4 biggest reasons why inequality is bad for society. Retrieved from http://www.ideas.ted.com/the-4-biggest-reasons-why-inequality-is-bad-for-society/

Note 68. Hammond, op. cit., p. 19.

Note 69. For example, see Huget, J. L. (2012, October 15). A new take on the marshmallow test. The Washington Post. Retrieved from https://www.washingtonpost.com/blogs/the-checkup/post/a-new-takeon-the-marshmallow-test/2012/10/15/cee09a54-14b4-11e2-9a39-1f5a7f6fe945_blog.html?utm_term=.c 1bd69237490 or Critchfield, T. S. \& Kollins, S. H. (2011). Temporal discounting: Basic research and the analysis of socially important behavior. Journal of Applied Behavior Analysis, 101-122.

Note 70. Cummine, op. cit., p. 7.

Note 71. Knapp, Berman, and Guettabi, op. cit., pp. VI-1. 


\section{Appendix A}

\section{Foregone Earnings from Permanent Fund Dividends (\$ millions)}

\begin{tabular}{|c|c|c|c|}
\hline \multicolumn{4}{|c|}{$\begin{array}{l}\text { Appendix } 1 \\
\text { Foregone Earnings from Permanent Fund Dividends } \\
\text { (\$ millions) }\end{array}$} \\
\hline \multicolumn{2}{|r|}{ Dividend Amount* } & Total Return** & $\begin{array}{l}\text { Accumulative } \\
\text { Foregone Earnings }\end{array}$ \\
\hline 1982 & $\$ 470$ & $15.10 \%$ & $\$ 470$ \\
\hline 1983 & $\$ 177$ & $12.76 \%$ & $\$ 707$ \\
\hline 1984 & $\$ 159$ & $10.89 \%$ & $\$ 943$ \\
\hline 1985 & $\$ 209$ & $25.58 \%$ & $\$ 1,393$ \\
\hline 1986 & $\$ 296$ & $23.06 \%$ & $\$ 2,010$ \\
\hline 1987 & $\$ 375$ & $7.62 \%$ & $\$ 2,539$ \\
\hline 1988 & $\$ 428$ & $5.44 \%$ & $\$ 3,105$ \\
\hline 1989 & $\$ 443$ & $12.18 \%$ & $\$ 3,926$ \\
\hline 1990 & $\$ 474$ & $9.26 \%$ & $\$ 4,763$ \\
\hline 1991 & $\$ 477$ & $9.15 \%$ & $\$ 5,676$ \\
\hline 1992 & $\$ 479$ & $11.48 \%$ & $\$ 6,807$ \\
\hline 1993 & $\$ 501$ & $12.65 \%$ & $\$ 8,169$ \\
\hline 1994 & $\$ 526$ & $1.48 \%$ & $\$ 8,816$ \\
\hline 1995 & $\$ 537$ & $14.51 \%$ & $\$ 10,632$ \\
\hline 1996 & $\$ 617$ & $13.43 \%$ & $\$ 12,677$ \\
\hline 1997 & $\$ 719$ & $17.07 \%$ & $\$ 15,560$ \\
\hline 1998 & $\$ 871$ & $16.35 \%$ & $\$ 18,975$ \\
\hline 1999 & $\$ 1,014$ & $9.49 \%$ & $\$ 21,790$ \\
\hline 2000 & $\$ 1,145$ & $9.18 \%$ & $\$ 24,935$ \\
\hline 2001 & $\$ 1,085$ & $-3.26 \%$ & $\$ 25,207$ \\
\hline 2002 & $\$ 908$ & $-2.24 \%$ & $\$ 25,550$ \\
\hline 2003 & $\$ 660$ & $4.46 \%$ & $\$ 27,350$ \\
\hline 2004 & $\$ 551$ & $14.23 \%$ & $\$ 31,793$ \\
\hline 2005 & $\$ 505$ & $10.43 \%$ & $\$ 35,614$ \\
\hline 2006 & $\$ 658$ & $10.98 \%$ & $\$ 40,182$ \\
\hline 2007 & $\$ 985$ & $17.06 \%$ & $\$ 48,022$ \\
\hline 2008 & $\$ 1,262$ & $-3.60 \%$ & $\$ 47,556$ \\
\hline 2009 & $\$ 811$ & $-17.96 \%$ & $\$ 39,826$ \\
\hline 2010 & $\$ 783$ & $11.72 \%$ & $\$ 45,276$ \\
\hline 2011 & $\$ 722$ & $20.56 \%$ & $\$ 55,307$ \\
\hline 2012 & $\$ 536$ & $-0.01 \%$ & $\$ 55,837$ \\
\hline 2013 & $\$ 568$ & $10.93 \%$ & $\$ 62,509$ \\
\hline 2014 & $\$ 1,189$ & $15.52 \%$ & $\$ 73,399$ \\
\hline 2015 & $\$ 1,273$ & $4.91 \%$ & $\$ 78,276$ \\
\hline 2016 & $\$ 650$ & $1.02 \%$ & $\$ 79,724$ \\
\hline $\begin{array}{l}\text { * Source: St } \\
\text { ** Source: A }\end{array}$ & $\begin{array}{l}\text { te of Alaska Departm } \\
\text { aska Permanent Func }\end{array}$ & $\begin{array}{l}\text { nt of Revenue, Per } \\
\text { Corporation }\end{array}$ & t Fund Dividend Div \\
\hline
\end{tabular}

